\title{
PHENOLOGICAL REPRODUCTIVE PATTERN OF THE Attalea speciosa Mart ex Spreng. IN PASTURE AREA IN THE CENTRAL REGION OF RONDÔNIA
}

\author{
Jhonatas Cortes Rosa $^{1 *}$, Andreza Pereira Mendonça ${ }^{2}$, Claudemir Carlos Ribeiro ${ }^{3}$, Sylviane Beck Ribeiro ${ }^{4}$ \\ ${ }^{1 *}$ Fundação Universidade Federal de Rondônia, Mestrado em Ciências Ambientais, Rolim de Moura, Rondônia, Brasil - \\ jhonatasagronomo@gmail.com \\ ${ }^{2}$ Instituto Federal de Educação Ciência e Tecnologia de Rondônia, Departamento de Engenharia Florestal, Ji-Paraná, Rondônia, Brasil - \\ mendonca.andreza@gmail.com \\ ${ }^{3}$ Centro Universitário São Lucas, Curso de Agronomia, Ji-Paraná, Rondônia, Brasil - claudemiragronomia@ gmail.com \\ ${ }^{4}$ Fundação Universidade Federal de Rondônia, Departamento de Engenharia Florestal, Rolim de Moura, Rondônia, Brasil - \\ sylvianebeck@unir.br
}

Received for publication: 04/12/2018 - Accepted for publication: 14/10/2019

\begin{abstract}
Resumo
Padrão fenológico reprodutivo de Attalea speciosa Mart ex Spreng. em área de pastagem na região central de Rondônia. O objetivo do trabalho foi avaliar a fenologia do babaçu (Attalea speciosa Mart ex Spreng.), visando subsidiar informações para o manejo não madeireiro da espécie em área de pastagens. Durante 48 meses, estudaram-se os padrões fenológicos do babaçu, relacionando-os com variáveis meteorológicas como temperatura média mensal, precipitação total mensal, umidade relativa do ar média e fotoperíodo. Foram monitoradas 130 palmeiras adultas provenientes de regeneração natural em uma pastagem no município de JiParaná, RO, no período de janeiro de 2012 a dezembro de 2015. Os dados foram analisados por meio dos índices de atividade, a relação das fenofases e variáveis meteorológicas por meio de correlação de Pearson. Foi avaliado também o índice de sincronia da população. Durante o estudo, a população de Attalea speciosa apresentou florescimento assincrônico na população. No processo de formação e amadurecimento dos frutos do babaçu, foi possível observar que o tempo de desenvolvimento total dos frutos foi em média 254 dias. Nas infrutescências jovens, os fatores climáticos de maior influência foram a temperatura e o fotoperíodo. Já nas infrutescências verdes, fatores climáticos como precipitação, umidade relativa do ar e fotoperíodo influenciaram de forma negativa. A presença de infrutescências maduras deu-se durante todo o ano, com as maiores intensidades no mês de novembro, tendo sua atividade relacionada ao aumento da temperatura e duração dos dias. $\mathrm{O}$ acompanhamento fenológico do babaçu permitiu identificar a intensidade e previsibilidade dos eventos reprodutivos, possibilitando assim subsidiar informações para os planos de exploração sustentável da espécie em pastagem no município de Ji-Paraná.
\end{abstract}

Palavras-chave: Babaçu, Manejo não madeireiro, Uso múltiplo, Infrutescência.

\section{Abstract}

The objective of this work was to evaluate the phenology of the babassu (Attalea speciosa Mart ex Spreng.), aiming to subsidize information for non - timber management of the species in pasture area. For 48 months, the phenological patterns of babassu were studied, relating them to meteorological variables such as monthly average temperature, monthly total precipitation, relative humidity of the medium air and photoperiod. A total of 130 adult palm trees from natural regeneration were monitored in a pasture in the municipality of Ji-Paraná, RO, from January 2012 to December 2015. The data were analyzed by means of the activity indexes, the relation of the phenophases and meteorological variables by means of Pearson correlation. The population synchrony index was also evaluated. During the study, the population of Attalea speciosa showed flowering asynchronously in the population. In the process of formation and maturation of the fruits of the babassu, it was possible to observe that the time of total development of the fruits was in average 254 days. In young infructescence, the most influential climatic factors were temperature and photoperiod. In the green infructescence, climatic factors such as precipitation, relative humidity and photoperiod influenced negatively. The presence of mature infructescence occurred throughout the year, with the highest intensities in the month of November, and its activity related to the increase in temperature and duration of days. Phenological monitoring of babassu allowed to identify the intensity and predictability of reproductive events, thus enabling information to be provided to the plans for the sustainable exploitation of the species in pasture in the municipality of Ji-Paraná.

Keywords: Babassu, Non-timber management, Multiple use, Infructescence. 


\section{INTRODUCTION}

In Rondônia the beef cattle and milk is expressive, with more than 63 thousand properties involved in the extensive ranching (IBGE, 2012). This activity, on present days, is under preassure to adjust to modern patterns of socio-environmental, sanitary and economical output (SILVA; BARRETO, 2014). With the implementation of the Pecuária Verde Programme, sustainable management techniques of pasture are demanded focusing the increase in the productivity of the areas. Among them, the recovery of legal protected environmentes and the afforestation of'the pastures stand out, providing comfort and well-being to the animals (FERRARINI; RAMOS, 2014).

A way to satisfy these requirements without encumber the producer is to use arboreal species originated of natural regeneration due to the multiservice delivery (animal comfort, nutrient cycling, maintenance of fauna and flora, supply of food, economical and socio-cultural use, among others) to the development of the livestock activity (ANDRADE et al., 2012).

To that end, the phenological studies of the species with this potential are fundamental. This study enables to gather nformation about the period of growth and reproduction of the plants. It is regulated by its edogenous characteristics to variations of the climate, not to mention abiotic and biotic factors, which are factors of selective preassure to the development of phenological patterns (SANTOS; FERREIRA, 2013).

The climate variables more related to the phenological events are temperature, the photoperiod, the precipitation, the environmental umidity and the water stress (BAUER et al., 2012), especially in tropical environments which present certain seasonality along the year (GUILHERME et al., 2011).

To know the phenological features of the species allows to: comprehend the dyamic of this population with great economical, the reproductive strategy and the decision making in programmes of managent of nonwood product, as well as the recontistuition of degraded areas (SANTOS; FERREIRA, 2013), also enabling the prodicer to adequate to a schedulling in time and space regarding the resources that those offer (MENDONÇA et al., 2014).

Among the special with multiple use potencial in the estate of Rondônia, The babassu stands out (Attalea speciosa Mart ex Spreng.), with the larger geographic distributio among the palm trees of the kind, originated in Brazil and that has as birth-place the North, Northeast and Central-West regions. Also there is a strong prensence in the states of Amazonas, Acre, Rondônia, Pará, Tocantins, Goiás, Maranhão, Piauí, Ceará, Bahia, Mato Grosso, Mato Grosso do sul and Minas Gerais (LORENZI, 2010).

In the estate of Rondônia, this palm tree is found largely distributed in the main types of formations of the Open Ombrophilous Forest, being abundant in the altered and with human impact areas such as pastures and poultries (BENTES-GAMA et al., 2007). The use of its fruit became one of the main extractive products of Brazil, generating many economical activities, what allows more than 300 thousand families to survive from is extractivism (FERNANDEZ, 2013).

There many studies about the fruit: The epicarp is used, for example, in the manufacture of tree fern fiber, upholstered furniture, particleboards, thermal insulator and organic fertilizers and also in the generation of energy (PROTÁSIO et al., 2014); the mesocarp has been used by the human and animal food industry and also by the pharmaceutical industry (ROSA et al., 2017).

However, the constraints in the non-wood use of the babaçu in Rondônia to the income generation is due to, beyond the lack of information about the intrinsic characteristics of the species, the influence of the climate variations over the phenology, regulating the season, the intensity, the duration and the frequency of the phenological events, mainly the reproductive. Therefore, the identification of the period with higher raw material availability facilitates to estabilish a sustainable exploitation pattern of the species.

In view of this question, the objective of this work was to ecaluate the phenology of the Attalea speciosa Mart ex Spreng. In a pasture in the city of Ji-Paraná (Rondônia), relating the phenological data with the climate variables looking to subsidize information to the non-wood management of the species.

\section{MATERIAL E METHODS}

\section{Profiling of the study area}

The phenological monitoring of the babaçu palm tree (Attalea speciosa Mart ex Spreng.) occurred in a pasture constituted by Brachiaria brizantha Stapf. cv. marandu, with low hadling intensity and extensive pasture in the city of Ji-Paraná (1050'51,59”S; 6153'47,12”W; Alt.: $182 \mathrm{~m}$ ), cemtral region of the estate of Rondônia, Brazil.

During the period of monitoring a hydric défice occurred (average rainfall inferior to $60 \mathrm{~mm}$ monthly for more than three months. RIGHT; VAN SHAIK, 1994) in the years of 2012 and 2015. This values are atipycal to the region and possibly would interfere in the phenological patterns of the palm trees in that periods (Figure $2 \mathrm{C}$ ). The average temperatre is $25,3{ }^{\circ} \mathrm{C}$ during the period of study (Figures $2 \mathrm{C}$ ) was very close to the climatic average 
of 10 years $\left(25,2^{\circ} \mathrm{C}\right)$ (Figures $\left.2 \mathrm{~A}\right)$. The duration of the days varied between 11,5 to 12,7 $\mathrm{h}$ in 48 months (Figure 2B).
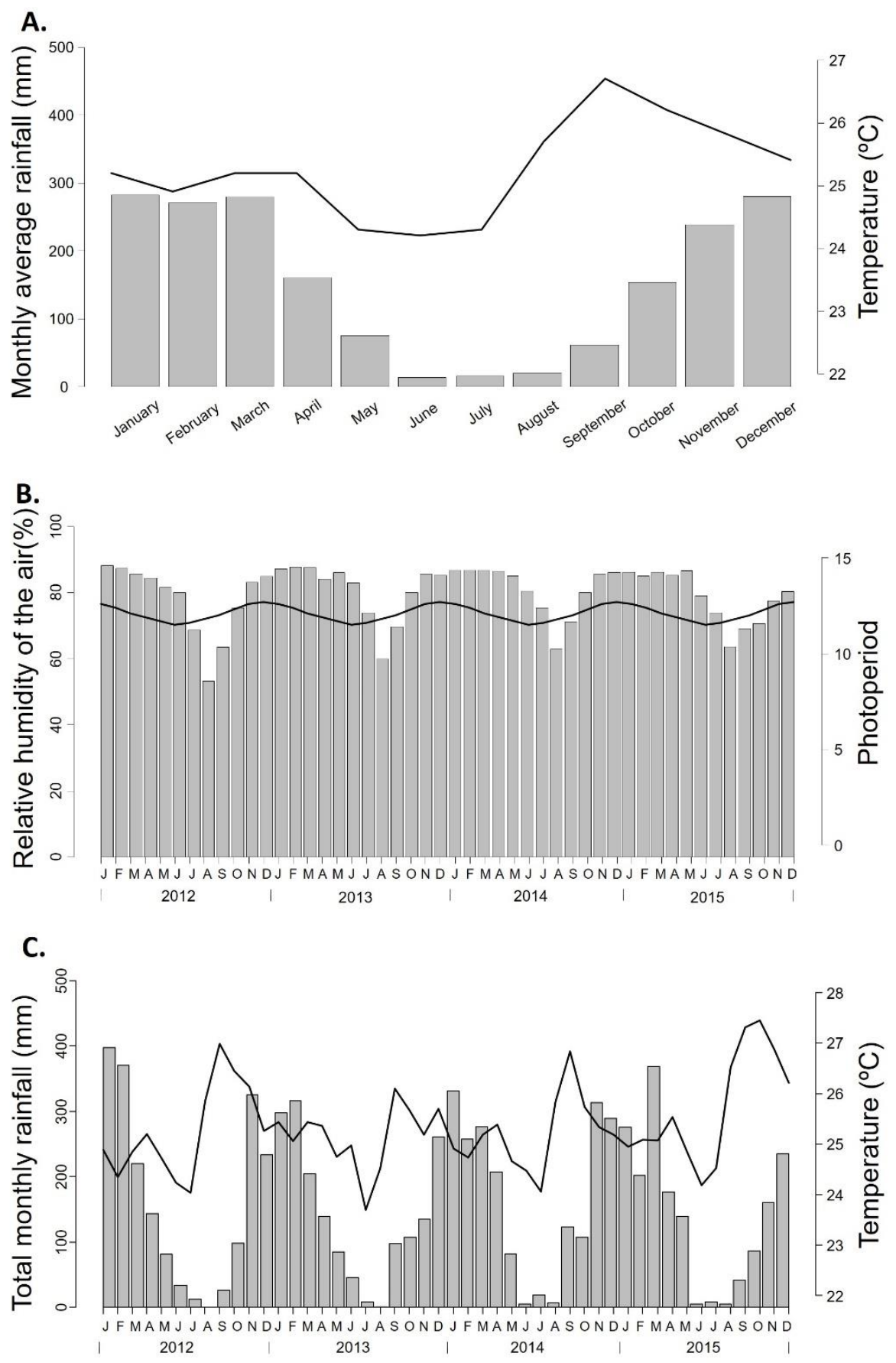

Figura 2. Caracterização climática para a região de Ji-Paraná, RO. (A.) Precipitação média mensal (colunas) e temperatura média mensal (linha) para uma série temporal de 10 anos (2006-2015); (B.) Umidade relativa do ar médio mensal (colunas) e fotoperíodo mensal (linha) do período de estudo (janeiro de 2012 a dezembro de 2015); e (C.) Precipitação total mensal (colunas) e temperatura média mensal (linha) do período de estudo (janeiro de 2012 a dezembro de 2015). (Fonte: CEPLAC-RO).

Figure 2. Climatic characterization for the region of Ji-Paraná, RO. (A) Monthly average rainfall (columns) and average monthly temperature (line) for a 10-year time series (2006-2015); (B.) Relative humidity of the monthly average air (columns) and monthly photoperiod (line) of the study period (January 2012 to December 2015); and (C.) Total monthly rainfall (columns) and average monthly temperature (line) of the study period (January 2012 to December 2015). (Source: CEPLAC-RO). 


\section{Phenological behavior}

130 individuals of bagassu in reproductive fase were monitored, originated from natural regeneration in a 15,4 ha pasture area. The individuals were identified with aluminium platelets. The phenological monitoring was conducted mensaly, from january of 2012 to december of 2015, totalling 48 meses uninterrupted of observation. The monitoring included two reproductive phenophases: I - flowering - view of the inflorescence (anthisis) (Figure 1A) and II-fructification - subdivided in young infructescenses (Figure 1B); green infructescenses (Fignura 1C) and mature infructescenses (Figura 1D) - this last one initiates with the dropping of the fruit and lasts until the end of the spread. When green and mature fruits occurred in the same infructescence, they were considered as ripe according to the same observations made by Begnini et al. (2013) (Figure 1D).
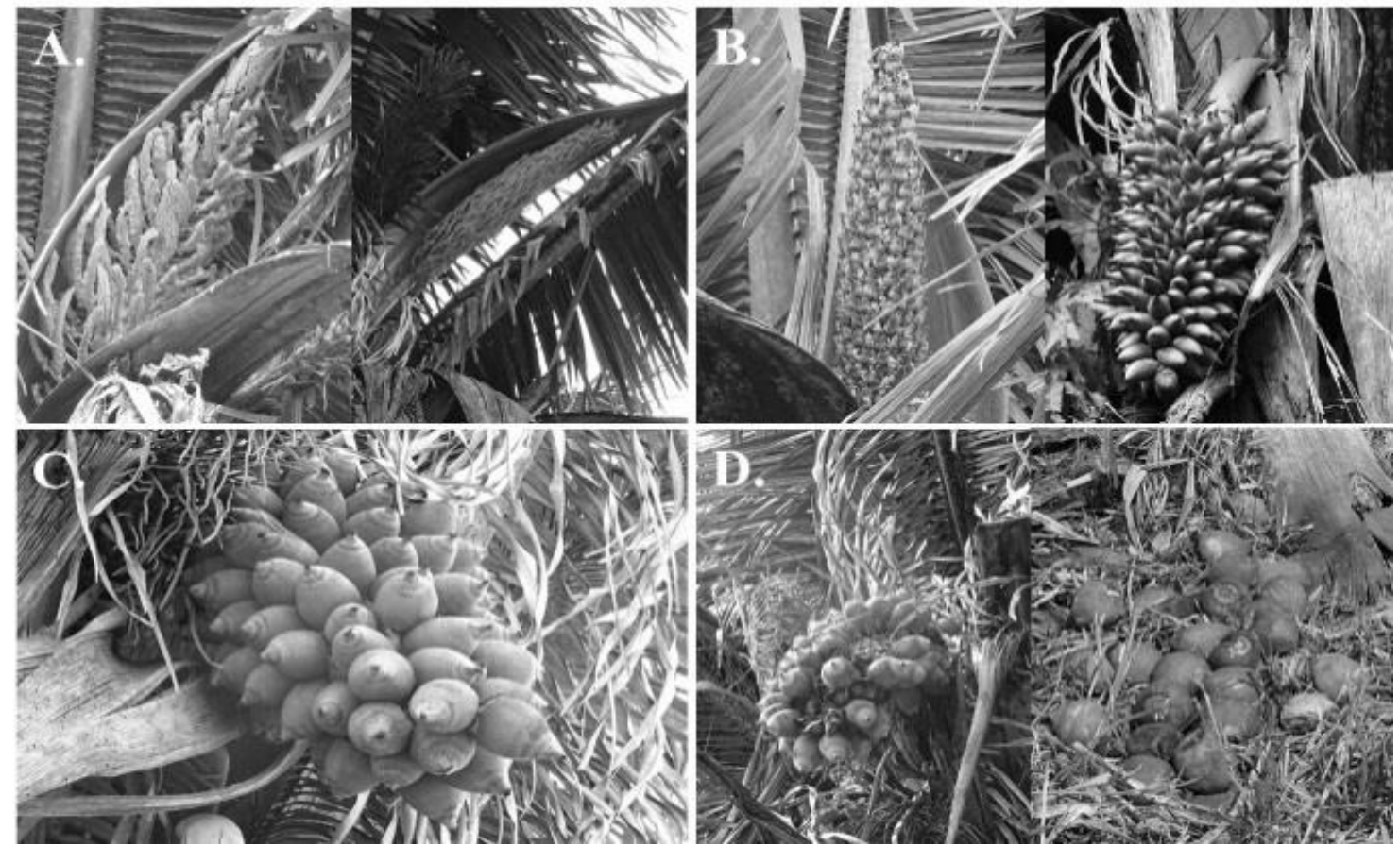

Figura 1. Fenofases do babaçu (Attalea speciosa Mart ex Spreng.) encontrado em pastagem na região central de Rondônia: (A) Inflorescência (antese); (B) Infrutescências jovens; (C) Infrutescências verdes; e (D) Infrutescências maduras.

Figure 1. Phenophases of the babassu (Attalea speciosa Mart ex Spreng.) found in pasture in the Central Region of Rondônia: (A) Inflorescence (anthesis); (B) Young infructescenses; (C) Green infructescence; and (D) Mature infrutescences.

To the analysis of the data, the activity index was applied. This indicator consists in registering the occurrence and absence of the reproductive event in each individual. It also allows to estimate the synchrony between the individuals of the population, taking into consideration that, the bigger the number of individuals manifasting the phenophase at the same time, the bigger synchrony of the population, the asynchronous phenological event was consisidered, rate of $<20 \%$ of individuals in phenophase; low synchrony to rate of 20 to $60 \%$; and high synchrony to rates $>60 \%$ of individuals manifasting the phenophase (BENCKE; MORELLATO, 2002; SANTOS; FERREIRA, 2013). It was considered the peak of determined phenologival event when more than $50 \%$ of the individuals present the same phenophase (BENCKE; MORELLATO, 2002). Each month the number of inflorescences and infructescences of each palm tree was qualified and their associated monthly average, estimating the intesity rate based on the monthly average of each phenophase, according to the methodological description of Begnini et al. (2013).

In the data collection of the development period of the fruit, a common average was made based on the monthly monitoring of 1 (one) cluster by palm tree in a year, since the outcrop of the fruit until full ripe, being 130 clusters by year and a total of 520 clusters in the period of the study.

The climatological data (monthly average of temperature, monthly total precipitation, environmental umidity and photoperiod utilized in the study were collected alongside with the weather station of the CEPLAC in Ouro Preto D'Oeste, Rondônia (1043'49,18' 'S; 62 13 '42,68' 'W). The photoperiod utilized was collected from the interactive anuary of the Observatório Nacional (ON) (ON, 2016). 
To verify the relation between monthly average of reproductive structures of each phenophase and the weather variables, the correlation coefficient of Pearson was determined (r) (FIGUEIREDO FILHO; SILVA JÚNIOR, 2009). Since it is a coefficient that measure the linear correlation degree of two quantitative variables, this one measured the monthly total precipitation, average environmental umidity and photoperiod, checking if the link bewteen weather variables and frequecy of reproductive phenophases of the species existed, exhibiting the direction of the relation if positive or negative. To that end the $R$ version 3.1.2 was used (R CORE TEAM, 2015).

\section{RESULTS}

\section{Flowering}

It was noted that the flowering occurred along the whole study, with record of at least one palm tree presenting inflorescence in the month. The higher intensity of inflorescence by palm tree were observed in the months of july of 2012, april of 2013, december of 2014 e november of 2015 (Figure 3).

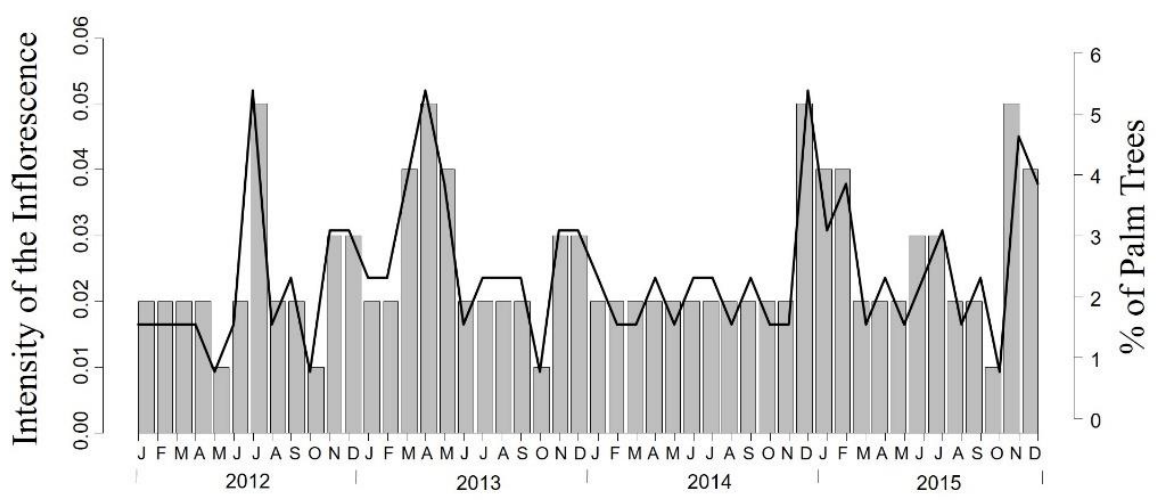

Figura 3. Representação fenológica baseada no índice de intensidade (barra) e atividade (linha) de Inflorescências, entre janeiro de 2012 e dezembro de 2015 no município de Ji-Paraná, RO.

Figure 3. Phenological representation based on the intensity index (bar) and activity (line) of the Inflorescences, between January 2012 and December 2015 in the municipality of Ji-Paraná, RO.

The inflorescence phenophase did not correlate with the weather variables in none of the evaluated periods and remained asynchronous from the population.

\section{Fructification}

The process of formation and maturing of the fruits of the babaçu occurred along the whole year, enabling to observe mensaly all the different stages of development of the fruits (Figuras 4, 5 e 6 ). The phenological cycle of the babassu presented a overlap of the phases of the young and green infructescences in the evaluated years. In the months of may and june it was possible to observe more than $50 \%$ of the palm trees with two phenophases.

During the monitoring of the full development of the fruits of the Attalea speciosa, it was possible to estimate that since the outcrop until its full maturing, that ends with its fall, it took 254 days.

The different phases of development of the infructescences were considered seasonal, because it presented significative correlations with the temperature, precipitation, umidity and photoperiod, manifesting in posite or negative manner to that climate factors.

\section{Young Infructescences}

The event presented low synchrony in the months that had a bigger number of palm trees expressing this phenophase, that in the periods of 2012, 2013 e 2015. As for the period of 2014, the peak of young infructescences occurred from may to july, presenting high synchrony among the population (Figure 4). 


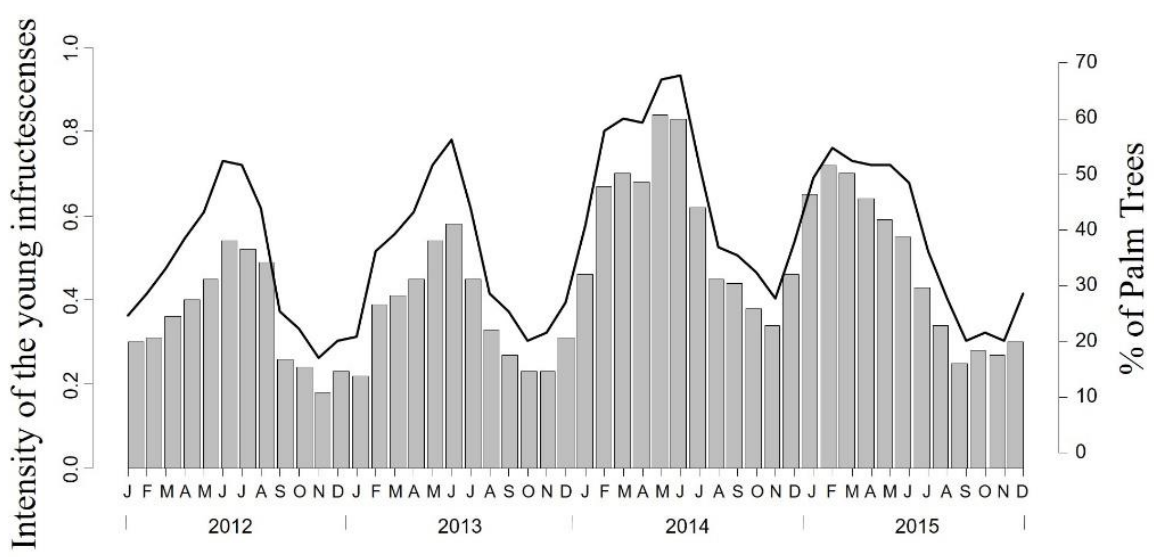

Figura 4. Representação fenológica baseada no índice de intensidade (barra) e atividade (linha) de Infrutescências jovens, entre janeiro de 2012 e dezembro de 2015 no município de Ji-Paraná, RO.

Figure 4. Phenological representation based on the intensity index (bar) and activity (line) of the Young infructescenses, between January 2012 and December 2015 in the municipality of Ji-Paraná, RO.

In the young infructescences, the climate factors of higher significative influence were temperature and photoperiod. In the year of 2012, the phenophase correlated negatively with the temperature $(r=-0,608 ; p<0,05)$ e fotoperíodo $(r=-0,891 ; p<0,001)$. In 2013, this correlation was also negative only with the photoperiod $(r=-$ $0,770 ; p<0,01)$. As for 2014, the temperature and the photoperiod correlated negatively $(r=-0,584 ; p<0,05$ e $r$ $=-0,642 ; p<0,05$, respectivamente). In 2015, the temperature and the environmental umidity correlated with the phenophase, the first time negatively $(r=-0,779 ; p<0,01)$ and the second positively $(r=0,797 ; p<0,01)$.

Green Infructesences

The green infuctescences were also observed during the whole year, although expressed in a very variable manner (21 a 85\%). It was noted that the peaks of activity occurred in different months along the evaluated years (Figure 5).

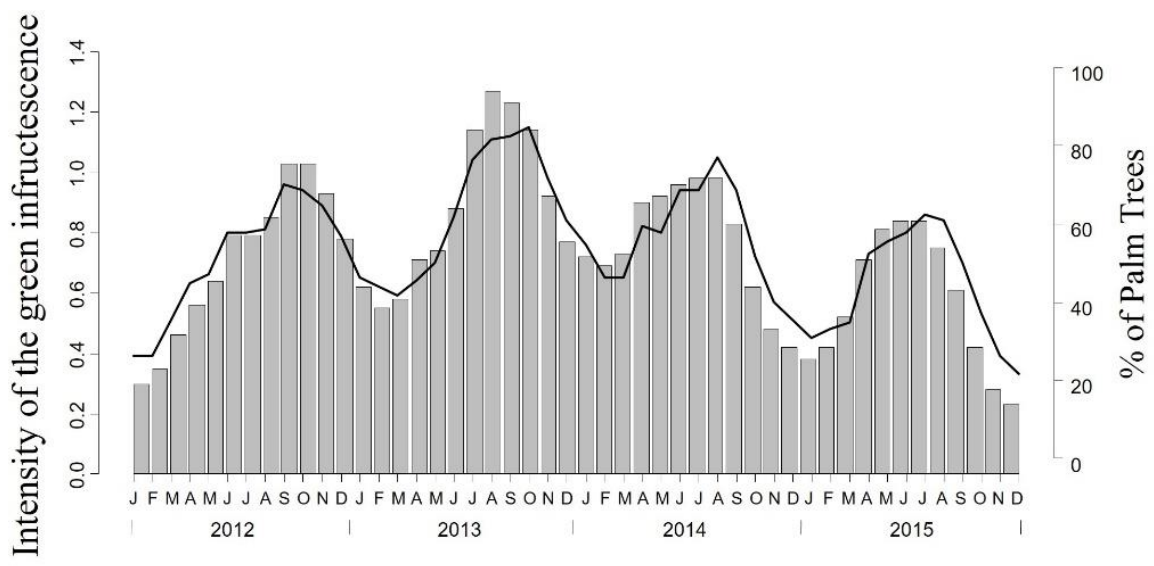

Figura 5. Representação fenológica baseada no índice de intensidade (barra) e atividade (linha) de Infrutescências verdes, entre janeiro de 2012 e dezembro de 2015 no município de Ji-Paraná, RO.

Figure 5. Phenological representation based on the intensity index (bar) and activity (line) of the Green infructescenses, between January 2012 and December 2015 in the municipality of Ji-Paraná, RO.

The climate factors of higher influence over the green infructescences were precipitation, umidity and photoperiod, all negatively. In 2012, this phenophase correlated positively with the temperature $(\mathrm{r}=0,654 ; \mathrm{p}<$ $0,05)$ and negatively with precipitation $(r=-0,623 ; p<0,05)$ and the environmental umidity $(r=-0,625 ; p<0,5)$. There was also negative correlation with precipition $(r=-0,772 ; p<0,01)$ and umidity $(r=-0,873 ; p<0,001)$ in 2013. As for 2014 and 2015, a negative correlation with precipitation occurred $(r=-0,763 ; p<0,01$ e $r=-0,599$; $\mathrm{p}<0,05$, respectively) and with photoperiod $(\mathrm{r}=-0,918 ; \mathrm{p}<0,001$ e $\mathrm{r}=-0,985 ; \mathrm{p}<0,001$, respectively). 


\section{Mature Infructescences}

The presence of mature fruits happened during the whole year, exhibiting a lasting availability of fruits, although with variations of 5 to $32 \%$ in the offer of the palm trees associated to the periods of higher temperatures and photoperiod, indicating a unleashing of maturing by the increase in temperature and duration of the day. The months with higher activity were observed between july and february during the period of evaluation (Figure 6).

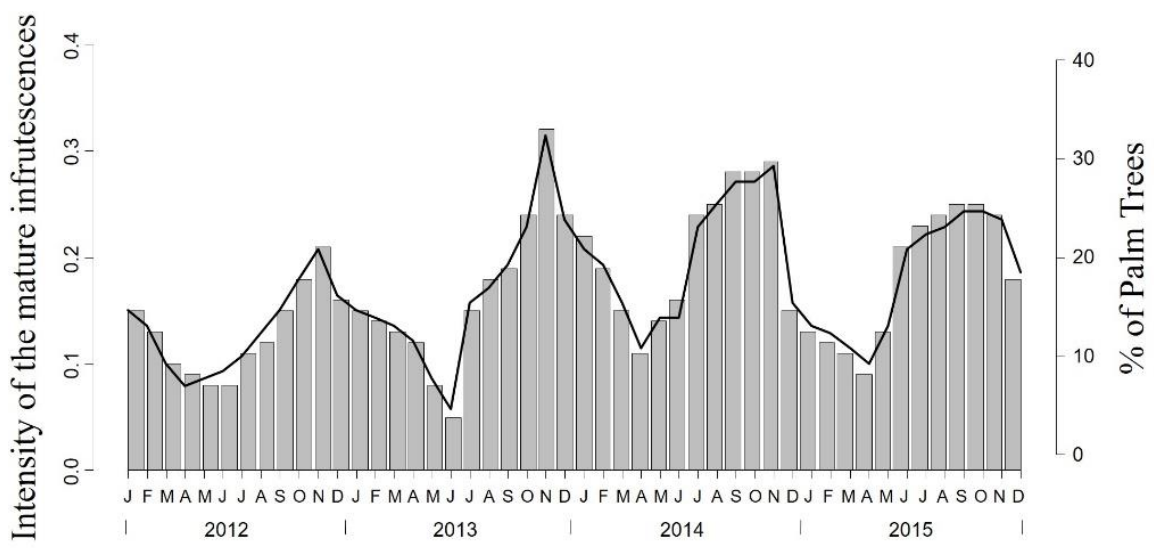

Figura 6. Representação fenológica baseada no índice de intensidade (barra) e atividade (linha) de Infrutescências maduras, entre janeiro de 2012 e dezembro de 2015 no município de Ji-Paraná, RO.

Figure 6. Phenological representation based on the intensity index (bar) and activity (line) of the Mature infructescenses, between January 2012 and December 2015 in the municipality of Ji-Paraná, RO.

This phenophase, in the year of 2012, positively correlated with the monthly average temperature $(\mathrm{r}=$ 0,637; $\mathrm{p}<0,05)$ and the photoperiod $(\mathrm{r}=0,781 ; \mathrm{p}<0,01)$. Although, in 2013, only the photoperiod $(\mathrm{r}=0,690$; p $>0,01$ ) was positively correlated. In 2014, none of the climatevariables influenced the phenophase. As for 2015 this phenophase was negatively influenced by monthly average precipitation $(r=-0,727 ; p<0,01)$ and the environmental umidity $(r=-0,888 ; \mathrm{p}<0,001)$.

During the phenological monitoring, it was noted that in the drought period (june to setember) the cattle consumed intesively the fruits, indicating that the fruit is palatable to the animals. It was also noted that there is a continuous period of flowering and fructification of babaçu along the year.

\section{DISCUSSION}

\section{Flowering}

The lack of synchronism of the phenophase verified in this study was also observed by Mendonça et al. (2014) in similar study, conducted in babaçu populations in ares of deforestation along the federeal highway BR 364, between the states of Acre and Rondônia. The authors also observed lack of synchronism in the inflorescences e sugested that this fact might be related to the deciduosiy of the male flowers of the babaçu, that fall imediately after the anthesis. The monitoring conducted each 30 days did not enable to specify accuretly this phenophase, which might have interference in the correlations between the inflorescences and climate variables, because the infructescences presented a minimum correlation with the climate variable. Based on that, it is recomended a more detailed monitoring.

In literature there are records about palm trees in which the flowering is not always regular and seasonal (SAMPAIO; SCARIOT, 2008), there are also record that those are influenced by climate variables, presentig seasonality (BEGNINI et al., 2013).

\section{Frutification}

The event of fruit formation of the babaçu in this study lasted an average of a little more than eight months (254 days). Similar behavior was observed by Araújo et al. (1996) in babaçuais growing in different types of soil in the state of Piauí, where the development of the fruit varied from 244 to 327 days until its maturing. As for Mendonça et al. (2014), studying native population of babassu in areas of deforestation to the generation of pasture in the state of Acre, observed that clusters in development took between 6 to 7 months to mature. This variation in the development time of the fruits of the babassu may be associated to various aspects, among them: soil and 
climate conditions and genetic variability of the species (SANTOS et al., 2014). Thus, it is evident the importance of the phenological monitoring, because this combined with the climate variables enables to subsidize information about anual production of the fruits and the harvest period.

The relantion between climate variables and the phenophases of young and green infructescences might be related to the flowering system of the species, which in this study was not possible to confirm due to the lack of synchronism presented by the inflorescences.

The relation of the young and green infructescences as well as its activities are associated to the climate variables, this relation is also intrinsically linked to the emission of inflorescences. This determinated the emergence of immature fruits, that occurs with higher frequency in palm trees in period of higher temperatures and ligh availiability (ARAÚJO et al., 1996; BEGNINI et al., 2013; MENDES et al., 2017).

The higher intensities of mature infructescences in the month of november that occurred during the study coincided with the beggining of the rain season in the region. This results were also obtained by Mendonça et al. (2014) by mapping the native population of the Orbignya phalerata in deforestation area to the generation of pastures in the state of Acre, where it was observed a higher intensity of mature infructescences in the begging of the rain season. Resende et al. (2007), characterizing a palm tree population in the state of Espirito Santo, verified that the species of the family of Arecaceae presented relation between production of fruits and the period of more umidity to the studied region (october to march), initiating the production in the beggining of the rain season.

The episode of hydric reduction occurred in the year of 2015, possibly caused a negative relation of the precipitation and environmental umidity with the maturing of the fruits, because in past years the maturing of the fruits related to the increase of temperature and photoperiod, which was also observed by Bauer et al. (2012) when the absence of hydric strress was mentioned, factors such as temperature and the photoperid seemed to positively influence fructification.

Studying reproductive phenology of the Syagrus romanzoffiana in the Rain Forest, Begnini et al. (2013) it was noted that the hydric defficiency occurred in the period of the study resulted in physological disturbs to the plant, causing a reduction in the reproductive intensity and activity of the palm tree. Thus, it is important to consider the climate monitoring in the non-wood management plan of the species, because when the hydric défice occurs, it might result in a decrease of production and/or its antecipation.

Although there are few records in literature about phenological monitoring of palm trees specially the babassu or even the absence of exploitation patterns to the forest species generators of non-wood products, the phenology can be a important tool to the pastoral management, since authors like Silva et al. (2012) demonstrate the viability of the use of the mesocarp of babassu in the increase in the beef carcass.

It is pointed out that the identification of the months of higher poduction of mature fruits (setember to november) is of the most importance to the determination of sustainable exploitation patterns of babassu in JiParaná, Rondônia.

\section{CONCLUSIONS}

- The population of Attalea speciosa Mart ex Spreng. Presented flowering along the entire study, although with no synchrony with the population.

- With the monitoring of the process of formation and maturing of the fruits of babassu along the year, it was possible to observe that the time of development of the fruits was in average 254 days.

- In young infructescences, the climate factors of higher infuence were temperature and photoperiod.

- Climate factors such as precipitation, environmental umidity and photoperiod influenced negatively the green infructescences.

- There is a higher availability of mature fruits in the periods of higher temperatures and photoperiod, between the months of july and february.

- The phenological monitoring of babassu enabled to identify the intensity and predictability of the reproductive events, facilitating to subsidize sustainable exploitation plans to the species in pasture of the city of Ji-Paraná.

\section{AKNOWLEDGEMENTS}

To Mr. Manoel de Souza Lima and Mrs. Lourdes da Penha Oaqes Lima for the permission to the conduction of the study in their property. To the Instituto Federal de Rondônia, campus Ji-Paraná by public notice of research $\mathrm{n}^{\circ} 013$ de 2014. To the Núcleo de Estudos em Agroecologia. To the Conselho Nacional de Desenvolvimento Científico e Tecnológico (CNPq) by pubic notice $\mathrm{n}^{\mathrm{o}} 058$ de 2010 for financial support. 


\section{REFERENCES}

ANDRADE, C. M. S.; SAlMAN, A. K. D.; OliVEIRA, T. K. Guia Arbopasto: Manual de identificação e seleção de espécies arbóreas para sistemas silvipastoris. Brasília: EMBRAPA, 2012. 345p.

ARAÚJO, E. C. E.; MENDES, A. M. C.; RIBEIRO, F. E. Comportamento fenológico do babaçu (Orbignya phalerala Mart.) em três tipos de solo do Piaui. Teresina: EMBRAPA-CPAMN, 1996. 15 p.

BAUER, D.; GOETZ, M. N. B.; MULLER, A.; SCHMITT, J. L. Fenologia de três espécies de Myrsine L. em floresta secundária semidecídua no Sul do Brasil. Revista Árvore, Viçosa, v. 36, n. 5, p. 859 - 868, 2012.

BEGNINI, R. M.; SILVA, F. R.; CASTELLANI, T. T. Fenologia reprodutiva de Syagrus romanzoffiana (Cham.) Glassman (Arecaceae) em Floresta Atlântica no sul do Brasil. Revista Biotemas, Florianópolis, v. 26, n. 4, p. 5360, 2013.

BENCKE, C. S. C.; MORELLATO, L. P. C. Estudo comparativo da fenologia de nove espécies arbóreas em três tipos de floresta atlântica no sudeste do Brasil. Revista Brasileira de Botânica, São Paulo, v. 25, n. 2 , p. 237 248,2002

BENTES-GAMA, M. de M.; VIEIRA, A. H.; LIMA, L. F.; OlIVEIRA, A. C. de; SILVA, A. P. F. F. da. Ocorrência de populações naturais de espécies não-madeireiras em Rondônia. Porto Velho: Embrapa Rondônia, 2007, 27p.

FERNANDEZ, A. J. C. Tendências e mudanças da produção agropecuária e extrativista na Amazônia: uma análise do censo agropecuário. In: SCHNEIDER, S.; FERREIRA, B.; ALVES, F. (Org.). Aspectos multidimensionais da agricultura brasileira: diferentes visões do Censo Agropecuário 2006. Brasília: Ipea, 2013, 387 p.

FERRARINI, C.; RAMOS, R. P. Pecuária Verde: produtividade, legalidade e bem-estar na fazenda. Paragominas: Sindicato dos Produtores Rurais de Paragominas, 2014, 124 p.

FIGUEIREDO FILHO, D. B.; SILVA JÚNIOR, J. A. Desvendando os Mistérios do Coeficiente de Correlação de Pearson (r). Revista Política Hoje, Recife, v. 18, n. 1, p. 115 - 146, 2009.

GUILHERME, F. A.; SAlGADO, A. A.; COSTA, E. A.; ZORTÉA, M. Fenologia de Cybistax antisyphilitica (Mart.) Mart. (Bignoniaceae) na região urbana de Jataí, Goiás. Bioscience Journal, Uberlândia, v. 27, n. 1, p. 138$147,2011$.

INSTITUTO BRASILEIRO DE GEOGRAFIA E ESTATÍSTICA. Produção da extração vegetal e da Silvicultura. Rio de Janeiro: IBGE, v. 27, 2012, 63 p.

LORENZI, H.; NOBLICK, L. R.; KAHN, F.; FERREIRA, E. J. L. Flora brasileira: Arecaceae (Palmeiras). Nova Odessa: Instituto Plantarum, 2010, 384 p.

MENDES, F. N.; VALENTE, R. M.; RÊGO, M. M. C.; ESPOSITO, M. C. Reproductive phenology of Mauritia flexuosa L. (Arecaceae) in a coastal restinga environment in northeastern Brazil. Brazilian Journal of Biology, São Carlos, v. 77, n. 1, p. 1 - 9, 2017.

MENDONÇA, C. C.; LIMA, A. F.; SILVA, G. M.; BARBOSA, C. S.; FERREIRA, E. J. L. Mapeamento de populações nativas, aspectos fenológicos e potencial de exploração de frutos de babaçu (Orbignya phalerata. Arecaceae) na Amazônia ocidental do Brasil. Enciclopédia Biosfera, Goiânia, v. 10, n. 18, p. 2138 - $2154,2014$.

OBSERVATÓRIO NACIONAL (ON). Fotoperíodo. Disponível em: 〈http://euler.on.br/ephemeris/index.php〉. Acesso em: 16 de janeiro 2016.

PROTÁSIO, T. P.; TRUGILHO, P. F.; CÉSAR, A. A. S.; NAPOLI, A.; MELO, I. C. N. A.; SILVA, M. G. Babassu nut residues: potential for bioenergy use in the North and Northeast of Brazil. SpringerPlus, London, v. 124, n. 3, p. 1 - 14, 2014.

R CORE TEAM. R: A Language and Environment for Statistical Computing. Vienna: R Foundation for Statistical Computing. Disponível em: < http://www.R-project.org>. Acesso em: 25 de janeiro 2015.

RESENDE, A. C. B.; BROETTO, G. C.; MALAQUIAS, J. L. T.; RIBEIRO, L. F. Caracterização de uma Comunidade de Palmeiras do Parque Natural Municipal do Goiapaba-Açú, Fundão, ES. Natureza on line, Santa Tereza, v. 5, n. 2, p. 68 - 75, 2007. 
ROSA, J. C.; MENDONÇA, A. P.; OLIVEIRA, A. dos S.; RIBEIRO, S. B.; BATISTA, A. do R.; ARAUJO, M. E. R. Drying kinetics of 'babassu' mesocarp. Revista Brasileira de Engenharia Agrícola e Ambiental, Campina Grande, v. 21, n. 10, p. 709 - 714, 2017.

SAMPAIO, M. B.; SCARIOT, A. Growth and reproduction of the understory palm Geonoma schottiana Mart. in the gallery forest in Central Brazil. Brazilian Journal of Botany, São Paulo, v. 31, n. 3, p. 433 - 442, 2008.

SANTOS, P. L.; FERREIRA, R. A. Fenologia de Tapirira guianensis Aubl. (Anacardiaceae) no município de São Cristóvão, Sergipe. Revista Árvore, Viçosa, v. 37, n. 1, p. 129 - 136, 2013.

SANTOS, R. R. M.; CAVALLARI, M. M.; PIMENTA, M. A. S.; ABREU, A. G.; COSTA, M. R.; GUEDES, M. L. Population genetic structure of Attalea vitrivir Zona (Arecaceae) in fragmented areas of southeast Brazil. Genetics and Molecular Research, Ribeirão Preto, v. 14, p. 6472 - 6481, 2014.

SILVA, D. S.; BARRETO, P. O aumento da produtividade e lucratividade da pecuária bovina na Amazônia: o caso do Projeto Pecuária Verde em Paragominas. Belém: IMAZON, 2014, 28 p.

SILVA, N. R.; FERREIRA, A. C. H.; FATURI, C.; SILVA, G. F.; MISSIO, R. L.; NEIVA, J. N. M.; ARAUJO, V. L.; ALEXANDRINO, E. Desempenho em confinamento de bovinos de corte, castrados ou não, alimentados com teores crescentes de farelo do mesocarpo de babaçu. Ciência Rural, Santa Maria, v. 42, n. 10, p. 1882 - 1887 , 2012.

WRIGHT, S. J.; VAN SCHAIK, C. P. Light and the phenology of tropical trees. The American Naturalist, Chicago, v. 143, n. 1, p. 192 - 199, 1994. 